\title{
EDGARS BERVALDS (1936-2019), LATVIAN SCIENTIST IN MECHANICAL ENGINEERING
}

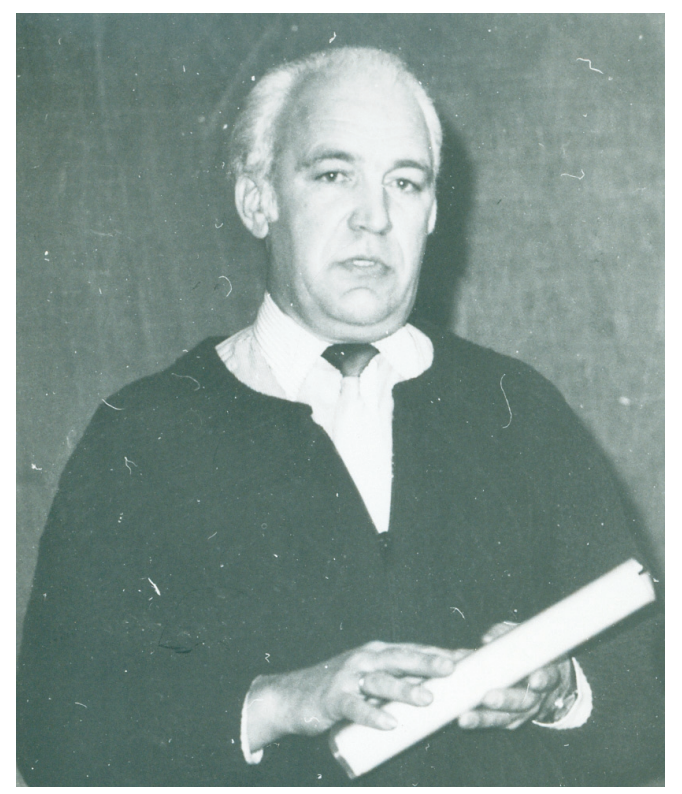

Edgars Bervalds, corresponding member of the Latvian Academy of Sciences since 2000, passed away on 29 May 2019 , at the age of 82 . He was the primary specialist in Latvia in design and construction of antennas and dishes for radio telescopes and interferometers.

Bervalds was born on 13 September 1936 in a fishermen's family in Mērsrags. After finishing the high school in Talsi in 1955, he graduated (1960) from the Rìga Polytechnical Institute as a construction engineer with his diploma work on a large radio telescope project, under the mentorship of the academician A. Mālmeisters. At that time, despite a general shortage of information, he succeeded in becoming familiar with issues in design and construction of parabolic antennas and of radio interferometers.

Bervalds was admitted to work in the Latvian Academy of Sciences, following an open competition for the position of chief engineer (1963) in the Astrophysical Laboratory. From that time, Bervalds was involved in, or in charge of, the design and construction of all the main facilities at that institution (in 1967 renamed as the Radioastrophysical Observatory). This included, e.g., domes for its Schmidt telescope, $55 \mathrm{~cm}$ reflectors, and the administration building.
The Presidium of the Latvian Academy of Sciences set up a small special design and technology team with four employees within this observatory to develop a design for a twoantenna radio interferometer with variable baselines. This project, having been elaborated during 1966-1970, was led by Bervalds and became highly appreciated by experts from the Radio Astronomy Council of the USSR Academy of Sciences; nevertheless, this innovative project could not be implemented due to the lack of necessary funds within the Latvian Academy.

Bervalds defended his thesis on 4 November 1980, in front of the Special Scientific Council of the Leningrad Institute of Civil Engineering. The title was "Исследования по созданию оптимальных схем силовых каркасов зеркал полноповоротных параболических антенн" (Research on the optimization of mechanical supports for fully movable parabolic antenna dishes), earning the degree of Candidate of Technical Sciences. A continuation of that work resulted in the publication of a 526-page monograph: Прецизионные конструкиии зеркальных радиотелескопов (Precision Design of Reflecting Radiotelescopes), with the co-author V. S. Poljak (Zinātne Publishers, Rìga, 1990). 
Other Soviet institutions grew interested in Bervald's work on the optimisation of mirror antenna structures, and in 1985, the USSR Academy Council for Radio Astronomy entrusted the Latvian observatory to organise an All-Union seminar on the modern design of radio telescopes.

In Rìga, September 1990, a larger-scale meeting of the International Union of Radio Science (URSI, Union RadioScientifique Internationale) assembled 36 Soviet and 14 Western specialists to discuss the possibilities of using the latest technologies in the construction of large-scale precision radio telescopes. The wide range of engineering interests of Edgars Bervalds was not limited to mirror antenna structures. Under his guidance, telescope domes in fiberglass were designed and manufactured, which were easier to operate and had better thermal and aerodynamic performance than traditional constructions. After the first two such domes had been installed to cover $55 \mathrm{~cm}$ reflectors at the
Riekstukalns site in Baldone, also the Moletai Astronomical Observatory of the Lithuanian Academy of Sciences and the Crimean Astrophysical Observatory acquired such modern $6.5 \mathrm{~m}$ diameter fiberglass structures for their astronomical domes, manufactured in the experimental workshop of the Radioastrophysical Observatory.

The engineer and constructor Edgars Bervalds and the radio astronomer Arturs Balklavs were the most knowledgeable specialists, thanks to whom Latvia was able to take over the valuable parabolic $32 \mathrm{~m}$ antenna from the former USSR Ministry of defense, making it a foundation for VIRAC, the Ventspils International Radio Astronomy Centre. Following its establishment as an independent institute, Dr.sc.ing. Professor Edgars Bervalds became its first director, serving 1995-2005.

Irena Pundure

\section{EDGARS BERVALDS (1936-2019) IZCILS LATVIJAS SPECIĀLISTS INŽENIERZINĀTNĒ}

Profesors, LZA korespondētājloceklis Edgars Bervalds aizgāja mūžībā 2019. gada 29. maijā 83. dzīves gadā. Viņš faktiski bija vienīgais speciālists radioteleskopu un radiointerferometru spoguḷantenu konstrukciju jautājumos Latvijā. E. Bervalds dzimis 1936. gada 13. septembrī Mērsraga zvejnieka ğimenē. Pēc Talsu vidusskolas beigšanas (1955) absolvējis Rīgas Politehnisko institūtu (1960). 1963. g. tika ievēlēts galvenā inženiera amatā LZA Astrofizikas laboratorijā. Kopš tā laika E. Bervalds piedalījās vai vadīja visu LZA Observatorijas galveno zinātnisko un komunālo būvju projektēšanu un celtniecību. Viņš bija Ventspils Starptautiskā radioastronomijas centra pirmais direktors (1995-2005). 